\title{
Is THE INTER-AmERICAN HUMAN RIgHTS SYSTEM Biased? A Quantitative Analysis of Regional Human Rights Litigation in The Americas
}

\author{
Simon Zschirnt \\ Department of Social Sciences, Texas A\&M \\ International University, Laredo, USA \\ simon.zschirnt@tamiu.edu
}

ZSCHIRNT, Simon. Is the Inter-American Human Rights System Biased? A Quantitative Analysis of Regional Human Rights Litigation in the Americas. International and Comparative Law Review, 2017, vol. 17, no. 1, pp. 51-81. DOI 10.2478/iclr-2018-0002.

\begin{abstract}
Summary: Although the Organization of American States' Inter-American human rights system has played a key role in the advancement of human rights, its work has recently become controversial. Some leftist governments have alleged bias, criticizing the system as a politicized one that prioritizes certain rights over others and embodies a neoliberal ideology that reflects disproportionate US influence. The system has also faced perceptions of cultural bias from Anglophone Caribbean states. This article tests the veracity of these allegations using statistical analysis of Inter-American Commission on Human Rights decisions. It finds that, even when controlling for a range of relevant factors, there have been significant differences in the Commission's receptiveness to different types of claims of human rights violations. However, the Commission's decisions have not exhibited any political or cultural biases. Also, to the extent there has been bias involving the United States, it has arguably been bias against the United States.
\end{abstract}

Keywords: Organization of American States, Inter-American human rights system, Inter-American Commission on Human Rights, strengthening process, Bolivarian Alliance for the Peoples of Our America

\section{Introduction}

Since its inception, the Inter-American human rights system has been widely hailed as "one of the most effective parts of the otherwise largely moribund Organization of American States (OAS)." Charged with the enforcement of the American Convention on Human Rights and the American Declaration of the Rights and Duties of Man, the system is comprised of the Inter-American Commission on Human Rights (IACHR), which receives and investigates petitions alleging human rights violations by OAS member states, and the Inter-American

1 BIRON, Carey L. Controversial Inter-American Reforms Process to Continue. [online]. Available at: <http://www.ipsnews.net/2013/03/controversial-inter-american-reformsprocess-to-continue/ $>$ 
Court of Human Rights (IACtHR), which adjudicates cases referred to it by the Commission. The Inter-American system, along with the European and African systems, currently stands as one of three regional human rights systems in which specialized human rights courts have legal authority to compel state compliance with human rights norms. With jurisdiction over a region that continues to be plagued by "paramilitary violence, summary executions, use of torture by police and brutal violations against detained individuals," the Inter-American system has been credited with having a "significant real world impact on human rights issues." Indeed, some stakeholders, such as José Miguel Vivanco, Human Rights Watch's Americas director, have gone as far as to argue that "[e]verything we have achieved on human rights issues in the region in the last thirty years is in some way a result of the work of the IACHR."3

Yet despite its role in the advancement of human rights in the Americas, the system's activism (i.e. its increasingly liberal interpretation of the Convention) has not always been welcomed and has increasingly become the subject of controversy. In particular, Bolivia, Ecuador, Nicaragua, Venezuela, and other states belonging to the Bolivarian Alliance for the Peoples of Our America (ALBA), an alliance of socialist and social democratic states, have criticized the IACHR and IACtHR as politicized institutions that focus on certain rights to the exclusion of others, exhibit bias against left-wing governments, and generally embody a neoliberal ideology that reflects the disproportionate influence of the United States and Canada (which are the system's major funders). ${ }^{4}$ For example, former Ecuadorian President Rafael Correa has denounced the IACHR and IACtHR as "vestiges of neoliberalism and neocolonialism" that apply "double standards" and are "captive of the interests of the hegemonic nations," Venezuelan President Nicolás Maduro has lambasted the system's "decadence," and Nicaraguan President Daniel Ortega has compared it to the Monroe Doctrine. ${ }^{5}$ These states and other critics of the system argue that under de facto American leadership the

2 CAVALLARO, James L. and BREWER, Stephanie E. Reevaluating Regional Human Rights Litigation in the $21^{\text {st }}$ Century: The Case of the Inter-American Court. American Journal of International Law, 2008, vol. 102, no. 4, pp. 768, 774, and 827.

3 Chipping at the Foundations. [online]. Available at: <http://www.economist.com/ node/21556599>

4 In 2016, the United States contributed $\$ 50$ million to the OAS while Canada contributed $\$ 9$ million. The next largest contributor after the United States was Brazil, which contributed \$11 million. See OPPENHEIMER, Andrés. Trump May Weaken OAS - And Efforts to Restore Democracy in Venezuela. [online]. Available at: <http://www.miamiherald.com/ news/local/news-columns-blogs/andres-oppenheimer/article138719758.html>

5 Correa Calls for New Inter-American Human Rights System. [online]. Available at: <https://www.efe.com/efe/english/life/correa-calls-for-new-inter-american-human-rightssystem/50000263-3064355>; President Correa: We Need to Create a Human Rights System for Latin America. [online]. Available at: <http://www.andes.info.ec/en/news/presidentcorrea-we-need-create-human-rights-system-latin-america.html>; PICQ, Manuela. Is the Inter-American Commission on Human Rights Too Progressive? [online]. Available at: $<$ http://www.aljazeera.com/indepth/opinion/2012/06/2012658344220937.html> 
system has "geared away from safeguarding human rights and liberties towards acting more like America's voice in the region," unfairly targeting its (mostly leftwing) adversaries while ignoring human rights violations by its (mostly rightwing) allies. ${ }^{6}$

Moreover, these critics maintain that this bias is reflected not only in the IACHR and IACtHR's jurisprudence, which they argue has been biased and in excess of the system's mandate in several areas, but also in discrepancies in funding for the system's thematic rapporteurships, which are responsible for monitoring states' compliance with their obligations under the Convention and Declaration. In particular, critics have noted that the rapporteurship for freedom of expression receives significantly more funding than other rapporteurships, such as those dedicated to the rights of women, children, and indigenous peoples, and operates under a special mandate that places it outside of the IACHR. ${ }^{7}$ This has led to allegations of "hierarchization" by a system that embodies a narrow and distinctly neoliberal conception of human rights, one that prioritizes negative rights and liberties over social justice. ${ }^{8}$

However, defenders of the system argue that what is really behind these critiques are the autocratic tendencies of some ALBA member states, tendencies that have increasingly made them the legitimate targets of human rights litigation before the IACHR and IACtHR. For example, not only has the suppression of political dissent in Venezuela been condemned on numerous occasions, most notably in the IACtHR's decisions ordering the Venezuelan government to lift a ban prohibiting opposition leader Leopoldo López from running for office and to reinstate the broadcasting license of Radio Caracas Televisión, Ecuador's use of libel law against opposition media outlets has also drawn a formal rebuke, with the IACHR issuing precautionary measures in 2012 that ordered the Ecuadorian government to release newspaper editors jailed for allegedly libeling President Correa. ${ }^{9}$ Venezuela in particular has also featured regularly in Chapter Four of the IACHR's annual reports, which identifies states that have engaged

6 HOLMUND, Caroline. Why Latin America Is Refusing to Follow the US on Human Rights. [online]. Available at: <https://www.foreignpolicyjournal.com/2014/04/10/why-latinamerica-is-refusing-to-follow-the-us-on-human-rights/>

7 See RUIZ-CHIRIBOGA, Oswaldo R. Is Ecuador That Wrong? Analyzing the Ecuadorian Proposals Concerning the Special Rapporteurship on Freedom of Expression of the InterAmerican Commission on Human Rights. Human Rights Brief, 2013, vol. 20, no. 2, pp. $26-33$.

$8 \quad$ Id. at 28.

9 López Mendoza v. Venezuela, Merits, Reparations, and Costs, Judgment, Inter-Am. Ct. H.R. (ser. C) No. 233 (Sept. 11, 2011); Granier et al. (Radio Caracas Televisión) v. Venezuela, Preliminary Objections, Merits, Reparations, and Costs, Judgment, Inter-Am. Ct. H.R. (ser. C) No. 293 (June 22, 2015); Emilio Palacio, Carlos Nicolás Pérez Lapentti, Carlos Pérez Barriga, and César Pérez Barriga, Precautionary Measures 406/11, Inter-Am. Comm'n H.R., OEA/Ser.L/V/II.147, doc. 1 rev. 1 (2013). 
in systematic patterns of serious human rights violations. ${ }^{10}$ Indeed, as of early 2017 there have been seventeen published IACHR merits reports responding to allegations of human rights violations committed by the Venezuelan government in the period since 1999, the year Hugo Chávez assumed the presidency and initiated his "Bolivarian Revolution." Only the United States, with twenty, has had more allegations of human rights violations committed during this period result in published merits reports.

Whatever the validity of these critiques, the fact that they have come from democratically elected governments has meant that they have been taken far more seriously than previous allegations that the system is biased, which mostly came from military dictatorships. ${ }^{11}$ Thus, they ultimately succeeded in pressuring the OAS to initiate a reform process that culminated in 2013 with the approval of a package of changes to the system's procedures. ${ }^{12}$ Most of the changes, which most notably included clarification of the criteria for issuing precautionary measures, were technical changes that aroused little controversy. ${ }^{13}$ However, the fact that the final resolution committed the OAS to continuing the reform process was harshly criticized by many human rights activists. For example, Lisa Reinsberg, the executive director of the International Justice Resource Center, argued that the primary effect of this will be to "divert attention away from important human rights concerns" insofar as the IACHR will be required to spend more time and resources responding to suggestions from states. ${ }^{14}$ Similarly, Tirza Flores, a Honduran judge who represented a coalition of more than 150 NGOs during the process, denounced the entire process as a "political process" intended by regimes with poor human rights records to weaken the system. ${ }^{15}$ Although the most controversial proposals, such as limiting the IACHR's power to issue precautionary measures, ending the publication of annual reviews of states' human rights records, and reducing funding for the special rapporteurship for freedom of expression, were defeated, the four states (Bolivia, Ecuador, Nicaragua, and Venezuela) that were the primary proponents of these proposals have declared that they remain committed to seeing them enacted. ${ }^{16}$

10 With the exception of the 2004 report, every annual report published by the IACHR since 2003 has included a special section focusing upon the human rights situation in Venezuela. Only Cuba, which has featured in Chapter Four every year since 1985, has been the subject of more persistent attention by the IACHR.

11 ARRIAGADA, Milenko B.G. The New Legitimacy Challenges of Adjudication at the InterAmerican Human Rights System in the Context of Latin American Democracies. SJD dissertation, American University, 2015, pp. 1-2.

12 Rules of Procedure of the Inter-American Commission on Human Rights (Mar. 18, 2013) [hereinafter IACHR Rules]. Reprinted in Basic Documents in the Inter-American System, 2011 [hereinafter Basic Documents].

13 Id. Art. 25.

14 BIRON, supra note 1.

15 Id.

16 OAS Concludes Formal Inter-American Human Rights "Strengthening" Process, but Dialogue Continues on Contentious Reforms. [online]. Available at: <http://www.ijrcenter. 
This backlash against the Inter-American system and the changes that it has precipitated (and may still precipitate) were the spur for a recent study analyzing the social backgrounds of victims in cases in which the IACHR and IACtHR have found human rights violations. Notably, it found no evidence to support one of the major claims of the ALBA member states: that the Inter-American system has systematically favored economic, cultural, and political elites. ${ }^{17}$ Although claims that the system has been used by powerful minorities to "overrule democratic decisions that have been supported by national majorities in their historical political struggle to enhance social justice" have been central to the narrative promoted by many of the system's critics, the social backgrounds of victims contradict such assertions. ${ }^{18}$ Even when the term "elite" is defined quite broadly to include not only politicians, members of the military, church officials, entrepreneurs, and landowners but also professionals and human rights and labor activists, only around thirty percent of the cases in which human rights violations have been found involved victims from this class. ${ }^{19}$ Although this finding is important to the ongoing debate surrounding the future of the Inter-American system, there are limits to the inferences that can be drawn from purely descriptive statistics.

In addition to the ideological divide that has fueled this controversy, there have also been cultural and regional divides in the system that have led other states to perceive bias as well. In particular, an "Anglo-Latin divide" has been evident throughout the system's history, with English-speaking states feeling marginalized in a system dominated by Latin American states. ${ }^{20}$ Not only have the system's procedures and juristic philosophy been modeled on the civil law legal systems of Latin America rather than the common law legal systems of North America and the Anglophone Caribbean, Spanish has been the system's dominant working language and English-speaking states have been underrepresented on the staffs of both the IACHR and IACtHR. ${ }^{21}$ They have also been notably underrepresented on the IACtHR itself. None of the seven judges currently sitting on the IACtHR hail from English-speaking states and only four of the thirty-nine judges who have served in the IACtHR's history have been Anglophones. ${ }^{22}$ The IACHR, however, has been somewhat more representative in this respect insofar as it has consistently had at least one commissioner hailing

org/2013/03/24/oas-concludes-formal-inter-american-human-rights-strengthening-process-but-dialogue-continues-on-contentious-reforms/>

17 ARRIAGADA, supra note 11 , at 112-63.

18 Id. at 123.

19 Id. at 140.

20 CAROZZA, Paolo. The Anglo-Latin Divide and the Future of the Inter-American System of Human Rights. Notre Dame Journal of International \& Comparative Law, 2015, vol. 5, no. 1, p. 153.

21 Id. at 159-67.

22 This despite the fact that English-speaking states comprise fourteen of the OAS's thirty-five member states. 
from an English-speaking state and nineteen of the seventy commissioners who have served in its history have been Anglophones. Nonetheless, as Mónica Pinto notes, the result of their underrepresentation in the other aforementioned areas has been that these states "do not feel at home [and] the great majority of them remain in the margins of the system and do not take advantage of it." ${ }^{23}$

This underlying tension has at times escalated to outright backlash as some Anglophone Caribbean states have publicly attacked the IACHR and IACtHR. The most notable example of this occurred in 1998, when Trinidad \& Tobago became the first state to denounce its ratification of the Convention after it refused, in the face of several cases pending before the IACHR, to modify its death penalty procedures to comply with the Convention's due process provisions. ${ }^{24}$ These tensions also contributed to the establishment by the member states of the Caribbean Community of their own supranational human rights court, the Caribbean Court of Justice, in 2005. ${ }^{25}$ As the subsequent reliance of national courts in several Anglophone Caribbean states upon Caribbean Court of Justice rather than IACtHR jurisprudence illustrates, the Caribbean court's "aim is clearly to develop a local case law that respects their traditions," something these states have sometimes felt is not the case in the Inter-American system. ${ }^{26}$ Persistent conflicts with the IACHR over the application of the death penalty have also led another English-speaking state, the United States, to publicly criticize the IACHR and "categorically reject" the proposition that the Declaration imposes any legally binding obligations on OAS members. ${ }^{27}$ Indeed, the fact that the IACHR and IACtHR have increasingly "interpret[ed] and appl[ied] the American Declaration and the American Convention in ways tending toward abolition of the death penalty" has been emblematic of the divide between Latin America, where there has been a near universal trend toward complete abolition of the death penalty, and the United States and the states of the Anglophone Caribbean, which retain and to varying degrees continue to impose the death penalty. ${ }^{28}$

23 PINTO, Mónica. The Crisis of the Inter-American System. Proceedings of the Annual Meeting of the American Society of International Law, 2013, vol. 107, p. 128.

24 See CONCEPCIÓN, Natasha P. The Legal Implications of Trinidad \& Tobago's Withdrawal from the American Convention on Human Rights. American University International Law Review, 2001, vol. 16, no. 3, pp. 847-90.

25 SHAVER, Lea. The Inter-American Human Rights System: An Effective Institution for Regional Rights Protection? Washington University Global Studies Law Review, 2010, vol. 9, no. 4, p. 675.

26 BURGORGUE-LARSEN, Laurence and ÚBEDA de TORRES, Amaya. The Inter-American Court of Human Rights: Case Law and Commentary. Oxford: Oxford University Press, 2011, p. 280.

27 WILSON, Richard J. The United States' Position on the Death Penalty in the Inter-American Human Rights System. Santa Clara Law Review, 2002, vol. 42, no. 4, p. 1160.

28 CAROZZA, supra note 20, at 163. 
The increasing activism that is reflected not only in this death penalty jurisprudence but also the Inter-American system's overall commitment to "progressive development" of the Convention has been attributed by Laurence Helfer to a wider phenomenon of "overlegalizing human rights." ${ }^{29}$ In particular, Helfer notes that the natural tendency of human rights regimes has been to evolve over time toward higher levels of "obligation, precision, and delegation" than were contemplated by signatory states at the time of their negotiation, levels of obligation, precision, and delegation that create tension for some states between domestic politics and international commitments. ${ }^{30}$ The extent to which this should be viewed approvingly depends not only upon one's conception of the nature of international law but also upon the extent to which the various allegations of bias that have been leveled against the system are true. That is, is the conventional view of the system as one that has successfully "circumvented...the politics that generally accompan[y] human rights discussions in the hemisphere" correct or are the system's critics correct that its decision-making processes have been affected by ideological and/or cultural biases? ${ }^{31}$

This article attempts to shed light upon this controversy through statistical analysis of the IACHR's jurisprudence. In doing so, it fills a significant gap in the literature on the Inter-American system, which has heretofore consisted almost exclusively of doctrinal analyses of select areas of the system's jurisprudence. By analyzing the full spectrum of the cases decided by the IACHR and controlling for a wide variety of potentially relevant factors, it will allow firmer conclusions to be drawn regarding the system's biases (or lack thereof). In particular, it will reveal whether the system has truly treated like cases alike in a way that goes beyond anecdotal comparisons of, for example, the system's response to the actions of right-wing military regimes in the 1970s and 80s and its response to the actions of left-wing populist regimes in the twenty-first century. The article proceeds as follows: the following section provides a brief overview of the InterAmerican system, the next section outlines the data and methods used in the analysis, and the final sections discuss the results and their implications.

\section{The Inter-American System in Brief}

The Inter-American human rights system is distinct from its more prominent European counterpart insofar as it is comprised of two institutions: the quasi-judicial IACHR and the judicial IACtHR. The IACHR serves as the decisionmaker of first instance for the system and is responsible for initial processing

29 HELFER, Laurence R. Overlegalizing Human Rights: International Relations Theory and the Commonwealth Caribbean Backlash against Human Rights Regimes. Columbia Law Review, 2002, vol. 102, no. 7, p. 1836.

30 Id. at 1910.

31 GROSSMAN, Claudio. The Inter-American System of Human Rights: Challenges for the Future. Indiana Law Journal, 2008, vol. 83, no. 4, p. 1274. 
of all petitions alleging violations of the Convention or Declaration. ${ }^{32}$ Its seven commissioners, who are elected by the OAS General Assembly to staggered four-year terms, are assisted in the processing of cases by staff attorneys from the OAS's secretariat. This arrangement has featured in the debate regarding the IACHR's alleged biases insofar as there has been a perception among some staff attorneys that commissioners are "more ideological and therefore less trustworthy to handle cases than the permanent staff." ${ }^{33}$ If a received petition complies with technical and procedural requirements and the IACHR decides that the facts alleged in the petition, if true, constitute a violation of the Convention or Declaration, it will declare the case admissible and attempt to mediate a friendly settlement between the petitioner(s) and the accused state. ${ }^{34}$ If the parties fail to settle, the case proceeds to the merits stage, both sides file briefs, and the IACHR sometimes holds hearings and/or conducts further investigation. ${ }^{35}$ The merits stage concludes when the IACHR files a report on the merits delivering its decision. If a state is found responsible for any human rights violations, it will be given a deadline to comply with the recommendations made in the IACHR's merits report. ${ }^{36}$ If it fails to do so, the IACHR will refer the case to the IACtHR provided that the state involved has made a declaration accepting the IACtHR's jurisdiction in contentious cases. ${ }^{37}$ Since Venezuela denounced its ratification of the Convention in 2012 at the height of the ALBA backlash, there remain twenty states with such a declaration in effect. ${ }^{38}$

Although the IACtHR has been the more prominent of the Inter-American system's two institutions insofar as its judgments (which, unlike the recommendations made by the IACHR, are legally binding) have often generated significant international publicity, this does not mean that the rendering of those judgments is the key stage in the processing of cases. This is because more than $99 \%$ of the cases litigated before the IACtHR have resulted in the IACtHR affirming the IACHR's conclusion that the accused state is responsible for human rights violations (despite the fact that review of cases by the IACtHR is formally de novo). ${ }^{39}$ Furthermore, outside of advisory opinions, the IACtHR has had no opportunity to adjudicate cases involving the United States and Canada, which have not rati-

32 Statute of the Inter-American Commission on Human Rights (Oct. 31, 1979). Reprinted in Basic Documents.

33 SHELTON, Dinah. The Rules and Reality of Petition Procedures in the Inter-American Human Rights System. Notre Dame Journal of International \& Comparative Law, 2015, vol. 5 , no. 1, p. 8.

34 IACHR Rules, supra note 12, Art. 37.

35 Id. Art. 37.

36 Id. Art. 44.

37 Id. Art. 45.

38 Argentina, Barbados, Bolivia, Brazil, Colombia, Costa Rica, Chile, the Dominican Republic, Ecuador, El Salvador, Guatemala, Haiti, Honduras, Mexico, Nicaragua, Panama, Paraguay, Peru, Suriname, and Uruguay

39 ARRIAGADA, supra note 11, at 118. 
fied the Convention, and most of the states of the Anglophone Caribbean, which have either not ratified the Convention at all or ratified the Convention but not accepted the IACtHR's jurisdiction in contentious cases. Consequently, few inferences regarding potential bias in the Inter-American system can be drawn from statistical analysis of the IACtHR's judgments. In contrast, the adjudication of petitions by the IACHR features significantly greater variance in outcomes and involves all OAS member states. Moreover, critics of the Inter-American system have recognized the importance of the IACHR's gatekeeping function and have directed their efforts to weaken the system accordingly. This is why the ALBA member states have been intent upon getting the OAS General Assembly to review the IACHR's statute and transform it from an institution with significant judicial power to a "mere diplomatic entity dedicated to the teaching and promotion of human rights in the region." ${ }^{40}$

\section{Research Methodology}

Given the centrality of IACHR decision-making to understanding possible bias in the Inter-American system, a comprehensive statistical analysis of its jurisprudence was conducted in order to assess the veracity of the allegations of bias that have been leveled against the system. The dataset upon which this analysis was based included every IACHR case (through 2015) that resulted in a published report on the merits. This included cases that were subsequently referred to and adjudicated by the IACtHR but excluded cases that ended in settlements. Because IACHR decision-making has been characterized by strong consensual norms and separate concurring or dissenting opinions have been relatively rare (separate opinions were filed in less than five percent of the cases in the dataset), the unit of analysis was decisions rather than the individual votes of commissioners. ${ }^{41}$ That is, the dependent variable was the IACHR's decision as to whether or not the accused state was responsible for human rights violations. Split decisions in which the accused state was found responsible for some of the violations that it was accused of but not for others were coded as two separate cases. Because the dependent variable was dichotomous, a logistic regression model was used to estimate the effects of the independent variables upon the likelihood of a finding of responsibility. These included:

\subsection{State Variables}

These variables consisted of measures of various characteristics of the states accused of human rights violations in these cases that may have affected the like-

40 Id. at 117.

41 In contrast, separate opinions are filed in more than forty percent of the cases decided by the seven judge chambers of the European Court of Human Rights (ECHR) and in nearly eighty percent of the cases decided by its seventeen judge grand chambers. See WHITE, Robin C.A. and BOUSSIAKOU, Iris. Separate Opinions in the European Court of Human Rights. Human Rights Law Review, 2009, vol. 9, no. 1, pp. 47-51. 
lihood of the IACHR finding them in violation of the Convention or Declaration. These included measures of states' levels of democratization, respect for the human rights of their citizens, and economic development, measures of the ideological orientations of their governments, and cultural/regional variables. Because a significant backlog has slowed the processing of cases, with an average of six and a half years elapsing between the initial submission of a petition and the IACHR's decision on the merits, the measures used in each case were from the year that the alleged human rights violation(s) occurred (as regimes accused of human rights violations were frequently no longer in power by the time a decision was rendered). ${ }^{42}$

\subsubsection{Polity Score}

Polity scores provide annual measures of states' authority characteristics. Scores range from -10 (autocracy) to 10 (full democracy). For each case, the accused state's Polity score for the year in which the alleged violation(s) occurred was used.

\subsubsection{CIRI Human Rights Index Score}

The Cingranelli-Richards (CIRI) Human Rights Index provides annual measures of states' respect for the human rights of their citizens. For each case, the accused state's score for the year in which the alleged violation(s) occurred on either the Physical Integrity Rights Index or the Empowerment Rights Index was used. The Physical Integrity Rights Index is an additive index measuring the incidence of human rights violations such as disappearance, extrajudicial killing, political imprisonment, and torture while the Empowerment Rights Index is an additive index measuring the incidence of violations of rights to electoral self-determination and freedom of assembly, association, movement, religion, and speech. Because the Physical Integrity Rights Index is an eight-point scale and the Empowerment Rights Index is a ten-point scale, scores were harmonized using percentage of maximum performance scaling. Physical Integrity Rights Index scores were used in cases involving claims of violations of rights to life, personal liberty and humane treatment, claims of violations of guarantees of due process of law, and claims of violations of the rights of the child. Empowerment Rights Index scores were used in cases involving claims of violations of rights to equal and effective participation in government and to freedom of conscience and religion, thought and expression, assembly, association, and movement and claims of violations of rights to equality, property, and privacy. In cases involving multiple claims that included claims in both categories, Physical Integrity Rights Index scores were used because the claims of violations of these rights tended

42 See DULITZKY, Ariel E. Too Little, Too Late: The Pace of Adjudication of the Inter-American Commission on Human Rights. Loyola of Los Angeles International \& Comparative Law Review, 2013, vol. 35, no. 2, p. 136. 
to be the dominant claims (i.e. the claims that were the primary focus of the IACHR's merits reports) in these cases.

Analysis of the European human rights system has found a significant positive relationship between the level of human rights abuse in a state (as measured by various human rights indices) and the number of petitions filed against the state as well as a weakly positive relationship between levels of human rights abuse and findings of state responsibility for human rights violations. ${ }^{43}$ However, the true strength of this effect is likely masked by the relative lack of variation in levels of human rights abuse among the (mostly) liberal democracies of Europe. Given the far greater variation in levels of democratization and human rights abuse that has existed in the Americas since the Inter-American system's creation, it was expected that claims against states with lower Polity and CIRI Human Rights Index scores would be significantly more likely to result in findings of violations of the Convention or Declaration.

\subsubsection{Adjusted Per Capita GDP}

For each case, the per capita gross domestic product of the accused state in the year in which the alleged violation(s) occurred (in 2016 US dollars) was used. Given that previous research has linked economic development with democratization, respect for human rights, and the capacity of states to maintain effective domestic systems of rights protection, it was expected that claims against states with lower per capita GDPs would be significantly more likely to result in findings of violations of the Convention or Declaration. ${ }^{44}$

\subsubsection{Acceptance of IACtHR Jurisdiction}

This variable controlled for whether, at the time that the alleged violation(s) occurred, a blanket acceptance by the accused state of the jurisdiction of the IACtHR in contentious cases was in effect. While the conventional wisdom would be that claims against states with such acceptances in effect would be significantly less likely to result in findings of violations of the Convention insofar as such states are likely to take their obligations under this treaty more seriously, scholars who conceptualize international human rights regimes as a form of "insurance" for transitional states argue that in certain cases the opposite may in fact be true. They argue that transitional states have often been the most enthusiastic supporters of international human rights regimes because these are the

43 See BOYLE, Elizabeth H. and THOMPSON, Melissa. National Politics and Resort to the European Commission on Human Rights. Law \& Society Review, 2001, vol. 35, no. 2, p. 338.

44 See, e.g., PRZEWORSKI, Adam et al. Democracy and Development: Political Institutions and Well-Being in the World, 1950-1990. Cambridge: Cambridge University Press, 2000; INGLEHART, Ronald and WELZEL, Christian. Modernization, Cultural Change, and Democracy. Cambridge: Cambridge University Press, 2005; EPSTEIN, David et al. Democratic Transitions. American Journal of Political Science, 2006, vol. 50, no. 3, pp. 551-69. 
states most likely to see such regimes as offering them concrete benefits. In particular, locking in new commitments to democracy and human rights provides transitional states insurance against backsliding by future governments while for established democracies the benefits are largely symbolic. ${ }^{45}$ This pattern, manifest in the creation of the European human rights system and the International Criminal Court, has also been manifest in differences in new and established democracies' postures toward the Inter-American system, with the established democracies of North America refusing to even ratify the Convention and the established democracies of the Anglophone Caribbean generally taking a much more ambivalent stance toward the system than the relatively new democracies of Latin America. Thus, while acceptance of the IACtHR's jurisdiction may signal a deeply rooted commitment to liberal values, it more likely signals the fragility of commitments to these values, fragility that creates a perceived need for external monitoring.

\subsubsection{Left/Right Party Government}

In order to test the veracity of the allegations of political bias that have been leveled against the Inter-American system, the ideological orientations of the governments of states accused of human rights violations were included in the model. States governed by socialist, social democratic, or other left-wing parties at the time of their alleged violation(s) of the Convention or Declaration were categorized as states with a left party government while states governed by Christian democratic or other right-wing parties were categorized as states with a right party government. States governed by centrist parties or non-partisan governments were the excluded reference category. Codings were based upon the World Bank's Database of Political Institutions.

\subsubsection{Cultural/Regional Variables}

Because it has not only been ideological divides within the OAS that have led to accusations of bias but also cultural and regional divides, states' cultural and regional identities were included in the model as well. The Americas were divided into three major cultural/geographic realms: North America, the Anglophone Caribbean, and Hispanophone Central/South America and Caribbean. North America consists of the United States and Canada, the Anglophone Caribbean consists of all of the Caribbean Basin's predominantly English-speaking states, and Hispanophone Central/South America and Caribbean consists of all Central American, South American, and Caribbean island states that are predominantly Spanish-speaking. OAS member states in which a language other than English

45 See MORAVCSIK, Andrew. The Origins of Human Rights Regimes: Democratic Delegation in Postwar Europe. International Organization, 2000, vol. 54, no. 2, pp. 217-52; ZSCHIRNT, Simon and MENALDO, Mark. International Insurance? Democratic Consolidation and Support for International Human Rights Regimes. International Journal of Transitional Justice, 2014, vol. 8, no. 3, pp. 452-75. 
or Spanish predominates (i.e. Brazil, Haiti, and Suriname) were the excluded reference category.

\subsection{Claim Variables}

These variables controlled for the type(s) of violation(s) of the American Convention on Human Rights or the American Declaration of the Rights and Duties of Man being alleged in these cases. Claims were grouped into seven general categories:

\subsubsection{Personal Integrity Rights}

Personal integrity rights are rights to personal liberty and freedom from severe physical harm at the hands of the state. These include the rights to life, humane treatment, freedom from slavery, and personal liberty guaranteed by Articles 4, 5, 6, and 7 of the Convention and Articles 1 and 25 of the Declaration.

\subsubsection{Civil and Political Rights}

Civil and political rights include the rights to freedom of conscience and religion, freedom of thought and expression, freedom of assembly, freedom of association, freedom of movement, and equal and effective participation in government guaranteed by Articles 12, 13, 15, 16, 22, and 23 of the Convention and Articles 4, 8, 20, 21, 22, and 24 of the Declaration.

\subsubsection{Rights to Equality}

Rights to equality include the rights to equality before the law and against discrimination on account of race, sex, language, creed, or any other factor guaranteed by Article 24 of the Convention and Article 2 of the Declaration.

\subsubsection{Property Rights}

Property rights include the rights to private property and against expropriation except upon payment of just compensation guaranteed by Article 21 of the Convention and Article 23 of the Declaration.

\subsubsection{Privacy Rights}

Privacy rights include the rights to personal dignity and honor and against arbitrary or abusive interference with individuals' personal lives, families, homes, and correspondence guaranteed by Article 11 of the Convention and Article 5 of the Declaration. 


\subsubsection{Judicial Guarantees}

Judicial guarantees include the rights to a fair trial, due process of law, and effective judicial protection guaranteed by Articles 8 and 25 of the Convention and Articles 18 and 26 of the Declaration.

\subsubsection{Rights of the Child}

Rights of the child include the special rights of minor children to the protection that is required by their condition as minors guaranteed by Article 19 of the Convention and Article 7 of the Declaration.

\section{Results}

Summary descriptive statistics are reported in Tables 1-6 and the results of the regression analysis are reported in Table $7 .{ }^{46}$ Overall, as Table 7 illustrates, the model performs very well in explaining the behavior of the IACHR. In particular, as indicated by the Pseudo $\mathrm{R}^{2}$ statistic, it explains nearly forty percent of the variance in case outcomes. ${ }^{47}$ More importantly, it indicates that there is no merit to most of the allegations of bias that have been leveled against the Inter-American human rights system but that there may be merit to some. In particular, contrary to the assertions of some socialist and social democratic regimes, there is no indication of any ideological bias against leftist governments. Not only did neither the "left party government" nor the "right party government" variable attain statistical significance, the signs of the coefficients of both variables were negative. This was true even when nominally non-partisan but clearly right-wing military regimes that are coded as "independent" in the Database of Political Institutions, such as the juntas that took power in Argentina and Uruguay in the 1970s, were recoded as right party governments.

\section{Table 1: Disposition on the Merits of IACHR Cases}

\begin{tabular}{|l|c|}
\hline \multicolumn{1}{|c|}{ Decision } & No. of Cases (\%) \\
\hline Responsible on all counts & $723(92.3)$ \\
\hline $\begin{array}{l}\text { Responsible on some counts, not respon- } \\
\text { sible on others }\end{array}$ & $33(4.2)$ \\
\hline Not responsible on all counts & $27(3.5)$ \\
\hline TOTAL & $783(100)$ \\
\hline
\end{tabular}

Table 2: Disposition on the Merits of IACHR Cases by Regime Type

46 Because Polity scores are not available for the Bahamas, Barbados, Belize, and Grenada and because CIRI Human Rights Index scores are not available for country-years before 1981, cases involving these states and cases involving alleged human rights violations committed before 1981 were not included in the regression analysis.

47 The $\mathrm{R}^{2}$ statistic indicates the proportion of the variance in the dependent variable that can be predicted by the independent variables. 


\begin{tabular}{|l|c|c|}
\cline { 2 - 3 } \multicolumn{1}{c|}{} & Left party government & Right party government \\
\hline $\begin{array}{l}\text { Responsible on } \\
\text { all counts }\end{array}$ & No. of Cases (\%) & No. of Cases (\%) \\
\hline $\begin{array}{l}\text { Responsible on } \\
\text { some counts, not } \\
\text { responsible on others }\end{array}$ & $226(90.8)$ & $282(91.0)$ \\
\hline $\begin{array}{l}\text { Not responsible } \\
\text { on all counts }\end{array}$ & $9(3.6)$ & $15(4.8)$ \\
\hline TOTAL & $249(100)$ & $13(4.2)$ \\
\hline
\end{tabular}

Table 3: Disposition on the Merits of North American IACHR Cases by State

\begin{tabular}{|l|c|c|c|c|}
\cline { 2 - 5 } \multicolumn{1}{c|}{} & $\begin{array}{c}\text { Responsible } \\
\text { on all counts }\end{array}$ & $\begin{array}{c}\text { Responsible } \\
\text { on some } \\
\text { counts, not } \\
\text { responsible } \\
\text { on others }\end{array}$ & $\begin{array}{c}\text { Not respon- } \\
\text { sible on all } \\
\text { counts }\end{array}$ & TOTAL \\
\hline Canada & $\begin{array}{c}\text { No. of Cases } \\
(\%)\end{array}$ & $\begin{array}{c}\text { No. of Cases } \\
(\%)\end{array}$ & $\begin{array}{c}\text { No. of Cases } \\
(\%)\end{array}$ & $\begin{array}{c}\text { No. of Cases } \\
(\%)\end{array}$ \\
\hline United States & $1(50.0)$ & $0(0.0)$ & $1(50.0)$ & $2(100.0)$ \\
\hline TOTAL & $28(96.5)$ & $0(0.0)$ & $1(3.5)$ & $29(100.0)$ \\
\hline
\end{tabular}

Table 4: Disposition on the Merits of Anglophone Caribbean IACHR Cases by State

\begin{tabular}{|l|c|c|c|c|}
\cline { 2 - 5 } \multicolumn{1}{c|}{} & $\begin{array}{c}\text { Responsible } \\
\text { on all counts }\end{array}$ & $\begin{array}{c}\text { Responsible } \\
\text { on some } \\
\text { counts, not } \\
\text { responsible } \\
\text { on others }\end{array}$ & $\begin{array}{c}\text { Not respon- } \\
\text { sible on all } \\
\text { counts }\end{array}$ & TOTAL \\
\hline \multicolumn{1}{|c|}{ State } & $\begin{array}{c}\text { No. of Cases } \\
(\%)\end{array}$ & $\begin{array}{c}\text { No. of Cases } \\
(\%)\end{array}$ & $\begin{array}{c}\text { No. of Cases } \\
(\%)\end{array}$ & $\begin{array}{c}\text { No. of Cases } \\
(\%)\end{array}$ \\
\hline The Bahamas & $4(66.7)$ & $2(33.3)$ & $0(0.0)$ & $6(100.0)$ \\
\hline Barbados & $2(100.0)$ & $0(0.0)$ & $0(0.0)$ & $2(100.0)$ \\
\hline Belize & $1(100.0)$ & $0(0.0)$ & $0(0.0)$ & $1(100.0)$ \\
\hline Grenada & $5(100.0)$ & $0(0.0)$ & $0(0.0)$ & $5(100.0)$ \\
\hline Guyana & $2(100.0)$ & $0(0.0)$ & $0(0.0)$ & $2(100.0)$ \\
\hline
\end{tabular}


ICLR, 2017, Vol. 17, No. 1.

\begin{tabular}{|l|c|c|c|c|}
\hline Jamaica & $9(52.9)$ & $1(5.9)$ & $7(41.2)$ & $17(100.0)$ \\
\hline $\begin{array}{l}\text { Trinidad \& } \\
\text { Tobago }\end{array}$ & $3(75.0)$ & $1(25.0)$ & $0(0.0)$ & $4(100.0)$ \\
\hline TOTAL & $26(70.3)$ & $4(10.8)$ & $7(18.9)$ & $37(100.0)$ \\
\hline
\end{tabular}

Table 5: Disposition on the Merits of Hispanophone Central/South America \& Caribbean IACHR Cases by State

\begin{tabular}{|l|c|c|c|c|}
\cline { 2 - 5 } \multicolumn{1}{c|}{} & Responsible & $\begin{array}{c}\text { Responsible } \\
\text { on some } \\
\text { counts, not } \\
\text { responsible } \\
\text { on others }\end{array}$ & $\begin{array}{c}\text { Not respon- } \\
\text { sible on all } \\
\text { counts }\end{array}$ & TOTAL \\
\hline Argentina & $\begin{array}{c}\text { No. of Cases } \\
\text { (\%) }\end{array}$ & $\begin{array}{c}\text { No. of Cases } \\
\text { (\%) }\end{array}$ & $\begin{array}{c}\text { No. of Cases } \\
\text { (\%) }\end{array}$ & $\begin{array}{c}\text { No. of Cases } \\
\text { (\%) }\end{array}$ \\
\hline Bolivia & $44(83.0)$ & $3(5.7)$ & $6(11.3)$ & $53(100.0)$ \\
\hline Chile & $16(94.1)$ & $1(5.9)$ & $0(0.0)$ & $17(100.0)$ \\
\hline Colombia & $43(91.7)$ & $1(2.8)$ & $2(5.5)$ & $36(100.0)$ \\
\hline Costa Rica & $3(75.0)$ & $0(0.0)$ & $1(25.0)$ & $4(100.0)$ \\
\hline Cuba & $26(100.0)$ & $0(0.0)$ & $0(0.0)$ & $26(100.0)$ \\
\hline $\begin{array}{l}\text { Dominican } \\
\text { Republic }\end{array}$ & $4(80.0)$ & $0(0.0)$ & $1(20.0)$ & $5(100.0)$ \\
\hline Ecuador & $27(90.0)$ & $2(6.7)$ & $1(3.3)$ & $30(100.0)$ \\
\hline El Salvador & $47(95.9)$ & $2(4.1)$ & $0(0.0)$ & $49(100.0)$ \\
\hline Guatemala & $93(97.9)$ & $1(1.1)$ & $1(1.1)$ & $95(100.0)$ \\
\hline Honduras & $17(89.5)$ & $1(5.3)$ & $1(5.3)$ & $19(100.0)$ \\
\hline Mexico & $16(66.7)$ & $7(29.2)$ & $1(4.2)$ & $24(100.0)$ \\
\hline Nicaragua & $32(100.0)$ & $0(0.0)$ & $0(0.0)$ & $32(100.0)$ \\
\hline Panama & $7(87.5)$ & $1(12.5)$ & $0(0.0)$ & $8(100.0)$ \\
\hline Paraguay & $20(90.9)$ & $2(9.1)$ & $0(0.0)$ & $22(100.0)$ \\
\hline Peru & $152(99.3)$ & $0(0.0)$ & $1(0.7)$ & $153(100.0)$ \\
\hline Uruguay & $11(84.6)$ & $1(7.7)$ & $1(7.7)$ & $13(100.0)$ \\
\hline Venezuela & $21(87.5)$ & $3(12.5)$ & $0(0.0)$ & $24(100.0)$ \\
\hline TOTAL & $612(93.3)$ & $27(4.1)$ & $17(2.6)$ & $655(100.0)$ \\
\hline
\end{tabular}


ICLR, 2017, Vol. 17, No. 1.

Table 6: Disposition of Claims Made to the IACHR by Claim Type

\begin{tabular}{|c|c|c|c|}
\hline & $\begin{array}{c}\text { Personal } \\
\text { integrity rights }\end{array}$ & $\begin{array}{c}\text { Civil and } \\
\text { political rights }\end{array}$ & Rights to equality \\
\hline Decision & No. of Claims (\%) & No. of Claims (\%) & No. of Claims (\%) \\
\hline Responsible & $632(96.5)$ & $114(91.2)$ & $45(75.0)$ \\
\hline Not responsible & $23(3.5)$ & $11(8.8)$ & $15(25.0)$ \\
\hline \multirow[t]{2}{*}{ TOTAL } & $655(100.0)$ & $125(100.0)$ & $60(100.0)$ \\
\hline & Property rights & Privacy rights & Judicial guarantees \\
\hline Decision & No. of Claims (\%) & No. of Claims (\%) & No. of Claims (\%) \\
\hline Responsible & $42(87.5)$ & $38(80.9)$ & $550(95.8)$ \\
\hline Not responsible & $6(12.5)$ & $9(19.1)$ & $24(4.2)$ \\
\hline \multirow[t]{2}{*}{ TOTAL } & $48(100.0)$ & $47(100.0)$ & $574(100.0)$ \\
\hline & Rights of the child & & \\
\hline Decision & No. of Claims (\%) & & \\
\hline Responsible & $58(95.1)$ & & \\
\hline Not responsible & $3(4.9)$ & & \\
\hline TOTAL & $61(100.0)$ & & \\
\hline
\end{tabular}


ICLR, 2017, Vol. 17, No. 1.

Table 7: Logit Model Predicting IACHR Declarations of Human Rights Violations

\begin{tabular}{l|l|}
\hline \multicolumn{1}{|c|}{ Variable } & Coefficient \\
\hline State variables \\
\begin{tabular}{|l|c|}
\hline Polity score & $-0.115^{*}(-2.34)$ \\
\hline CIRI Human Rights Index score (scaled) & $-2.036^{\star}(-2.39)$ \\
\hline Adjusted per capita GDP & $-0.001^{\dagger}(-1.88)$ \\
\hline Acceptance of IACtHR jurisdiction & $0.819(1.48)$ \\
\hline Left party government & $-0.341(-0.61)$ \\
\hline Right party government & $-0.805(-1.52)$ \\
\hline North America & $7.563^{* *}(2.71)$ \\
\hline Anglophone Caribbean & $-0.837(-0.72)$ \\
\hline $\begin{array}{l}\text { Hispanophone Central / South } \\
\text { America and Caribbean }\end{array}$ & $-0.349(-0.37)$ \\
\hline
\end{tabular}
\end{tabular}

Claim variables

\begin{tabular}{|l|c|}
\hline Personal integrity rights & $1.524^{\star *}(3.14)$ \\
\hline Civil and political rights & $1.236^{\star}(2.14)$ \\
\hline Rights to equality & $-0.930^{\dagger}(-1.86)$ \\
\hline Property rights & $-0.272(-0.44)$ \\
\hline Privacy rights & $-0.917(-1.42)$ \\
\hline Judicial guarantees & $2.672^{\star * *}(6.27)$ \\
\hline Rights of the child & $1.117(1.02)$ \\
\hline
\end{tabular}

\begin{tabular}{|l|c|}
\hline Log likelihood & $-112.778^{\star * *}$ \\
\hline Pseudo $\mathrm{R}^{2}$ & 0.376 \\
\hline $\mathrm{N}$ & 644 \\
\hline
\end{tabular}

Note: Entries in cells show logit coefficients with z-scores in parentheses ${ }^{\dagger} \mathrm{p}<0.10^{\star} \mathrm{p}<0.05^{\star \star} \mathrm{p}<0.01{ }^{\star \star \star} \mathrm{p}<0.001$ 
Instead, the results indicate that general measures of the human rights situations in the states involved in litigation before the IACHR are the best predictors of case outcomes. In particular, both states' Polity scores and their CIRI Human Rights Index scores at the time of their alleged human rights violations were statistically significant predictors of whether they would be found responsible for violations of the Convention or Declaration. All of these results are what would be expected of a non-politicized system that does a good job of distinguishing meritorious claims from frivolous claims. In a similar vein, states' levels of economic development were also a statistically significant predictor of case outcomes, with the greater likelihood of states with lower per capita GDPs being found responsible for human rights violations illustrative of the fact that such states often lack the resources to combat endemic human rights problems.

Also, despite the purported disproportionate influence that the United States and Canada enjoy as the Inter-American system's major funders, there is no evidence that these states have been the beneficiaries of favorable treatment when they have been accused of human rights violations. In fact, quite to the contrary, the logit model indicates that, other factors being equal, these states were significantly more likely to be found responsible for human rights violations when claims were brought against them. Given that twenty-nine of the thirty-one decisions in the dataset involving claims against North American states were decisions involving claims against the United States while only two were decisions involving claims against Canada, this apparent bias is perhaps better described as an anti-American bias rather than an anti-North American bias. Moreover, it is an apparent bias that is not simply an artifact of the IACHR's general antipathy toward the death penalty. Although claims by death row inmates were the most common type of claim made against the United States, the IACHR has also been called upon to adjudicate a wide variety of other types of claims against the United States. ${ }^{48}$ These have included claims challenging the United States' lack of protection for unborn children against abortion, its treatment of refugees and both documented and undocumented immigrants, its invasion and occupation of fellow OAS member Grenada in 1983, its denial of the rights of Native Americans to their ancestral lands, its denial of congressional representation to the residents of the District of Columbia, and its failure to protect women against domestic violence. ${ }^{49}$ Although the eighty-nine percent success rate for these non-death

48 Twenty of the twenty-nine cases brought against the United States involved challenges to the imposition of the death penalty.

49 'Baby Boy,' Case 2141, Inter-Am. Comm'n H.R., Report No. 23/81, OEA/Ser.L/V/II.54, doc. 9 rev. 1 (1981); Haitian Interdiction, Case 10.675, Inter-Am. Comm'n H.R., Report No. 51/96, OEA/Ser.L/V/II.95, doc. 7 rev. 1 (1997); Rafael Ferrer-Mazorra et al., Case 9903, Inter-Am. Comm'n H.R., Report No. 51/01, OEA/Ser.L/V/II.111, doc. 20 rev. 1 (2001); Andrea Mortlock, Case 12.534, Inter-Am. Comm'n H.R., Report No. 63/08, OEA/Ser.L/V/ II.134, doc. 5 rev. 1 (2009); Wayne Smith, Hugo Armendariz et al., Case 12.562, Inter-Am. Comm'n H.R., Report No. 81/10, OEA/Ser.L/V/II, doc. 5 rev. 1 (2011); Coard et al., Case 10.951, Inter-Am. Comm'n H.R., Report No. 109/99, OEA/Ser.L/V/II.106, doc. 6 rev. 1 
penalty claims was roughly in line with the overall success rate for petitioners before the IACHR, it was quite out of line with the success rate for cases brought against other states with similarly good performance on human rights indices such as Polity and CIRI. For example, in only fifty-eight percent of the cases brought against other states scoring a perfect ten on the Polity index was the state found responsible for all of the human rights violations that it was accused of. This is not to say that any of these decisions against the United States were wrong and anti-American bias is certainly not the only potential explanation for this result. ${ }^{50}$ For example, the strength of the American legal system in providing due process and protecting individual rights may ironically work against it insofar as cases involving the United States that result in received petitions and manage to make it past the admissibility stage may be particularly likely to involve strong claims. However, it does dispel the notion that the financial backing provided by the United States gives it special influence over the Inter-American system's decision-making processes and has led the IACHR, in the words of leading ALBA member states, to turn a "blind eye to human rights violations in the United States." 51

There is, however, no evidence whatsoever that the other bloc of Englishspeaking states in the Americas, the states of the Anglophone Caribbean, have been the subject of disparate treatment. Despite the aforementioned Anglo-Latin divide and the fact that Anglophone Caribbean states have also been frequent targets of death penalty litigation, these states were not significantly more likely to be found responsible for human rights violations. Thus, although there has been speculation that the underrepresentation of these states on the IACHR and IACtHR and their staffs has subjected them to bias, there is no evidence that cultural differences alone have contributed to unequal treatment. Not only do the descriptive statistics illustrate that cases involving claims against these states were actually considerably less likely to result in findings of responsibility (only seventy percent resulted in a finding of full responsibility compared to ninetytwo percent of cases overall), the sign of the "Anglophone Caribbean" variable was negative in the logit model. That is, findings of responsibility were less likely

(1999); Mary and Carrie Dann, Case 11.140, Inter-Am. Comm’n H.R., Report No. 75/02, OEA/Ser.L/V/II.117, doc. 1 rev. 1 (2003); Statehood Solidarity Committee, Case 11.204, Inter-Am. Comm'n H.R., Report No. 98/03, OEA/Ser.L/V/II.118, doc. 5 rev. 2 (2003); Jessica Lenahan (Gonzales) et al., Case 12.626, Inter-Am. Comm'n H.R., Report No. 80/11, OEA/Ser.L/V/II, doc. 69 rev. 1 (2011).

50 Nonetheless, perceptions of anti-American bias have been a major factor in recent efforts by some US politicians to defund the OAS. Ironically given the nature of the allegations of bias made by the ALBA member states, at the heart of these efforts has been the perception that the OAS is "an ally of anti-US regimes in Cuba and Venezuela." See ROGIN, Josh. House Panel Votes to Defund the OAS. [online]. Available at: <http://foreignpolicy. com/2011/07/20/house-panel-votes-to-defund-the-oas/>

51 RIVERA JUARISTI, Francisco J. US Exceptionalism and the Strengthening Process of the Inter-American Human Rights System. Human Rights Brief, 2013, vol. 20, no. 2, p. 19. 
even when controlling for these states' relatively high levels of democratization and relatively strong performances on human rights indices (although the effect was not statistically significant).

Indeed, even when it comes to the contentious issue of these states' continued imposition of death sentences, the IACHR's approach appears to have been driven more by a commitment to progressive development than by culturallybased death penalty abolitionism. While the IACHR has consistently held, over the course of a series of cases spanning nearly two decades and involving the Bahamas, Barbados, Grenada, Jamaica, and Trinidad \& Tobago, that sentencing laws that require the automatic imposition of the death penalty upon those convicted of murder violate the Convention, the basis for these decisions was a global trend among states retaining the death penalty toward requiring more individualized sentencing in capital cases and the jurisprudence of other international human rights bodies (such as the ECHR and the United Nations Human Rights Committee). ${ }^{52}$ That this is best understood as a commitment to a living document rather than an attempt to impose Latin American norms is illustrated by a series of earlier cases involving challenges to death sentences imposed in Jamaica. ${ }^{53}$ In these cases, the IACHR was willing to hold that these sentences

52 Haniff Hilaire et al., Case 11.816, Inter-Am. Comm'n H.R., Report No. 43/98, OEA/ Ser.L/V/II.106, doc. 6 rev. 1 (1999); Rudolph Baptiste, Case 11.743, Inter-Am. Comm'n H.R., Report No. 38/00, OEA/Ser.L/V/II.111, doc. 20 rev. 1 (2001); Desmond McKenzie et al., Case 12.023, Inter-Am. Comm'n H.R., Report No. 41/00, OEA/Ser.L/V/II.106, doc. 6 rev. 1 (1999); Michael Edwards et al., Case 12.067, Inter-Am. Comm'n H.R., Report No. 48/01, OEA/Ser.L/V/II.111, doc. 20 rev. 1 (2001); Donnason Knights, Case 12.028, InterAm. Comm'n H.R., Report No. 47/01, OEA/Ser.L/V/II.111, doc. 20 rev. 1 (2001); Leroy Lamey et al., Case 11.826, Inter-Am. Comm'n H.R., Report No. 49/01, OEA/Ser.L/V/ II.111, doc. 20 rev. 1 (2001); Joseph Thomas, Case 12.183, Inter-Am. Comm'n H.R., Report No. 127/01, OEA/Ser.L/V/II.114, doc. 5 rev. 1 (2002); Denton Aitken, Case 12.275, InterAm. Comm'n H.R., Report No. 58/02, OEA/Ser.L/V/II.117, doc. 1 rev. 1 (2003); Benedict Jacob, Case 12.158, Inter-Am. Comm'n H.R., Report No. 56/02, OEA/Ser.L/V/II.117, doc. 1 rev. 1 (2003); Paul Lallion, Case 11.765, Inter-Am. Comm'n H.R., Report No. 55/02, OEA/Ser.L/V/II.117, doc. 1 rev. 1 (2003); Dave Sewell, Case 12.347, Inter-Am. Comm'n H.R., Report No. 76/02, OEA/Ser.L/V/II.117, doc. 1 rev. 1 (2003); Lennox Boyce et al., Case 12.480, Inter-Am. Comm'n H.R., Report No. 03/06, OEA/Ser.L/V/II.127, doc. 4 rev. 1 (2007); Chad Roger Goodman, Case 12.265, Inter-Am. Comm’n H.R., Report No. 78/07, OEA/Ser.L/V/II.130, doc. 22 rev. 1 (2007); Tyrone Dacosta Cadogan, Case 12.645, InterAm. Comm'n H.R., Report No. 60/08, OEA/Ser.L/V/II.134, doc. 5 rev. 1 (2009); Peter Cash, Case 12.231, Inter-Am. Comm'n H.R., Report No. 12/14, OEA/Ser.L/V/II.150, doc. 16 rev. 1 (2014).

53 Noel Riley, Case 3102, Inter-Am. Comm'n H.R., Report No. 25/81, OEA/Ser.L/V/II.54, doc. 9 rev. 1 (1981); Davlin Morris, Case 3552, Inter-Am. Comm'n H.R., Report No. 60/82, OEA/Ser.L/V/II.61, doc. 22 rev. 1 (1983); Roosevelt Edwards, Case 7604, InterAm. Comm'n H.R., Report No. 7/84, OEA/Ser.L/V/II.63, doc. 10 rev. 1 (1984); Earl Pratt, Case 9054, Inter-Am. Comm’n H.R., Report No. 13/84, OEA/Ser.L/V/II.66, doc. 10 rev. 1 (1985); Lyndon Champagnie, Case 7505, Inter-Am. Comm'n H.R., Report No. 27/86, OEA/Ser.L/V/II.68, doc. 8 rev. 1 (1986); Wesley Cuthbert, Case 9190, Inter-Am. Comm'n H.R., Report No. 28/86, OEA/Ser.L/V/II.68, doc. 8 rev. 1 (1986). 
did not violate the human rights of the condemned when it was satisfied that they were the result of fundamentally fair proceedings. Although the IACHR revealed its abolitionist sympathies by recommending in each case that Jamaica consider abolishing the death penalty (sympathies that have since been periodically reaffirmed in a series of press releases and reports recommending abolition), it refrained from holding that the death penalty is inherently inconsistent with OAS members' human rights obligations. ${ }^{54}$ Thus, although the Inter-American system's application of the principle of progressive development in these and other cases has been criticized for being "too divorced from the consensual aspect of a regional human rights convention," it does not necessarily constitute evidence of cultural bias. ${ }^{55}$

Although the results provide no indication of political bias, bias in favor of the system's major funders, or bias against the Anglophone Caribbean states that have felt marginalized by the system, they do indicate that there may be merit to allegations that the system has embodied a neoliberal conception of human rights by taking certain rights more seriously than others. Specifically, consistent with complaints by the ALBA member states that the system has placed disproportionate emphasis upon rights to freedom of thought and expression and other negative rights and liberties, the logit model indicates that, other factors being equal, the IACHR was significantly more likely to find human rights violations in cases involving alleged violations of civil and political rights. Although the percentage of claims of violations of civil and political rights that resulted in findings of responsibility (ninety-one percent) was actually slightly lower than the overall percentage of claims that resulted in findings of responsibility (ninety-four percent), this was a significantly higher percentage than would be anticipated given the characteristics of the states involved. This illustrates how prominent cases in which the IACHR has found full democracies in violation of the right to freedom of thought and expression have been emblematic of the IACHR's general approach. These include, for example, Juan Pablo Olmedo Bustos et al., in which the IACHR condemned Chile's censorship on religious grounds of the film The Last Temptation of Christ, Mauricio Herrera Ulloa, in which the IACHR condemned a Costa Rican law requiring journalists sued for defamation to prove the truth of statements made by their sources, and Eduardo Kimel, in which the IACHR condemned the prosecution of an Argentine journalist for publicly speculating that pressure from the military contributed to a judge's failure to fully investigate the murders of five priests. ${ }^{56}$ In these cases and others, the IACHR

54 For the most prominent example of the IACHR's strong public advocacy of the abolition of the death penalty in the Americas, see INTER-AMERICAN COMMISSION ON HUMAN RIGHTS. The Death Penalty in the Inter-American Human Rights System: From Restrictions to Abolition. Washington: Organization of American States, 2011.

55 NEUMAN, Gerald L. Import, Export, and Regional Consent in the Inter-American Court of Human Rights. European Journal of International Law, 2008, vol. 19, no. 1, p. 123.

56 Juan Pablo Olmedo Bustos et al., Case 11.803, Inter-Am. Comm'n H.R., Report No. 31/98, OEA/Ser.L/V/II.102, doc. 6 rev. 1 (1999); Mauricio Herrera Ulloa, Case 12.367, Inter-Am. 
has applied an expansive interpretation of the right to freedom of thought and expression that allows few, if any, exceptions, one that has often resulted in states with otherwise very good human rights records being found in violation of the Convention or Declaration. ${ }^{57}$ This was also the case with regard to claims of violations of personal integrity rights and judicial guarantees, which, other factors being equal, were also significantly more likely than other types of claims to result in findings of violations of the Convention or Declaration.

Conversely, and potentially also consistent with complaints by the ALBA member states that the system has deemphasized issues of social justice, the logit model indicates that, other factors being equal, the IACHR was significantly less likely to find violations of the Convention or Declaration in response to claims of violations of rights to equality. In fact, twenty-five percent of such claims were rejected, the highest rejection rate of any of the claim types. Rejected claims included, for example, challenges to an Argentine law denying reparations to certain classes of victims of human rights violations committed during the country's period of military rule, to the Mexican government's alleged failure to vigorously prosecute members of a wealthy and politically influential family accused of murder, and to a Chilean university's abolition of a professor's professorship. ${ }^{58}$ However, as this sampling indicates, these rejected claims were not claims of discrimination on traditionally suspect grounds such as race and gender. Instead, they were claims of arbitrary treatment, many of which were rather vague. Thus, rather than reflecting bias, the IACHR's relative coolness to Article 24 claims is more likely a reflection of its reluctance to expand the scope of this article in a way that would lead to undue second-guessing of legislative and administrative judgments. ${ }^{59}$ The IACHR's restraint is noteworthy in light of the IACtHR's pathbreaking advisory opinion in Juridical Condition and Rights of the Undocumented

Comm'n H.R., Report No. 64/02, OEA/Ser.L/V/II.118, doc. 5 rev. 2 (2003); Eduardo Kimel, Case 12.450, Inter-Am. Comm'n H.R., Report No. 111/06, OEA/Ser.L/V/II.130, doc. 22 rev. 1 (2007).

57 For more on the Inter-American system's activist approach to freedom of thought and expression, see GROSSMAN, Claudio. Freedom of Expression in the Inter-American System for the Protection of Human Rights. Nova Law Review, 2001, vol. 25, no. 2, pp. 411-42; GROSSMAN, Claudio. Challenges to Freedom of Expression Within the Inter-American System: A Jurisprudential Analysis. Human Rights Quarterly, 2012, vol. 34, no. 2, pp. 361403.

58 Marcelino Hanríquez et al., Case 11.784, Inter-Am. Comm’n H.R., Report No. 73/00, OEA/Ser.L/V/II.111, doc. 20 rev. 1 (2001); Pedro Peredo Valderrama, Case 11.103, InterAm. Comm'n H.R., Report No. 42/00, OEA/Ser.L/V/II.106, doc. 6 rev. 1 (1999); Ricardo Israel Zipper, Case 12.470, Inter-Am. Comm'n H.R., Report No. 110/09, OEA/Ser.L/V/II, doc. 51 corr. 1 (2009).

59 As Commissioner Paolo Carozza noted in his concurring opinion in National Association of Ex-Employees of the Peruvian Social Security Institute et al., Case 12.670, Inter-Am. Comm'n H.R., Report No. 38/09, OEA/Ser.L/V/II, doc. 51 corr. 1, 12 (2009), the IACHR is not in the business of "second-guessing the state's reasonable, even if contestable, policy judgments." 
Migrants, which articulated an extremely broad principle of non-discrimination extending well beyond traditionally suspect forms of discrimination. ${ }^{60}$ Some have expressed concern that this is an unmanageable standard that could have "unpredictable and detrimental consequences" for the Inter-American system. ${ }^{61}$ However, the IACHR appears not to have taken this opinion as an invitation to a dramatically more expansive reading of Article $24 .{ }^{62}$

On the other hand, the IACHR was invariably receptive to Article 24 claims that did allege racial or gender discrimination. Indeed, some of its most significant twenty-first century decisions have come in response to such claims, such as its decision that the Dominican Republic's denial of nationality to members of its Haitian minority constitutes racial discrimination, its decisions condemning several states' mistreatment of indigenous communities, and its decision that provisions of the Guatemalan civil code allowing husbands to determine whether their wives may work outside of the home violate the equal rights of women. ${ }^{63}$ It has also begun to use Article 24 to condemn discrimination on the basis of sexual orientation, with the first such decision coming in 2009 in response to a Chilean court's revocation of a mother's custody of her children on grounds that she is a lesbian. ${ }^{64}$

However, one aspect of the IACHR's body of work that may lend support to these critiques is the paucity of cases involving claims of violations of economic, social, and cultural rights (and the IACHR's relative coolness toward such claims). Article 26 of the Convention commits states to the "full realization of the

60 Juridical Condition and Rights of the Undocumented Migrants, Advisory Opinion, InterAm. Ct. H.R. (ser. A) No. 18 (Sept. 17, 2003). In declaring a norm of non-discrimination jus cogens, the IACtHR defined discrimination as "any exclusion, restriction, or privilege that is not objective and reasonable and which adversely affects human rights."

61 NEUMAN, supra note 55, at 122.

62 This opinion did, however, provide one of the bases for the IACHR's recent decision in Undocumented Workers, Case 12.834, Inter-Am. Comm'n H.R., Report No. 50/16, OEA/ Ser.L/V/II.159 (2016), a case presenting a similar fact pattern involving the denial of labor rights to undocumented immigrants in the United States. As the IACtHR did in its advisory opinion, the IACHR condemned disparate treatment of undocumented immigrants on grounds that it lacks an "objective and reasonable" justification.

63 Yean and Bosico Children, Case 12.189, Inter-Am. Comm'n H.R., Report No. 30/03, OEA/ Ser.L/V/II.118, doc. 5 rev. 2 (2003); Maya Indigenous Communities of the Toledo District, Case 12.053, Inter-Am. Comm'n H.R., Report No. 40/04, OEA/Ser.L/V/II.122, doc. 5 rev. 1 (2005); Community of the Rio Negro of the Maya Achi Indigenous People and its Members, Case 12.649, Inter-Am. Comm'n H.R., Report No. 86/10, OEA/Ser.L/V/II, doc. 5 rev. 1 (2011); Kuna Indigenous People of Madungandi and Embera Indigenous People of Bayano and their Members, Case 12.354, Inter-Am. Comm'n H.R., Report No. 125/12, OEA/Ser.L/V/II.147, doc. 1 rev. 1 (2013); Residents of the Village of Chichupac and Neighboring Communities, Case 12.788, Inter-Am. Comm'n H.R., Report No. 100/14, OEA/ Ser.L/V/II.150, doc. 16 rev. 1 (2015); Maria Eugenia Morales de Sierra, Case 11.625, InterAm. Comm'n H.R., Report No. 4/01, OEA/Ser.L/V/II.111, doc. 20 rev. 1 (2001).

64 Karen Atala and Daughters, Case 12.502, Inter-Am. Comm'n H.R., Report No. 139/09, OEA/Ser.L/V/II, doc. 51 corr. 1 (2009). 
rights implicit in the economic, social, educational, scientific, and cultural standards set forth in the Charter of the Organization of American States." ${ }^{\prime 65}$ Yet there were only six cases in the dataset in which the IACHR adjudicated claims of violations of this article (or somewhat analogous positive rights provisions in the Declaration). ${ }^{66}$ This extremely small sample size precluded including economic, social, and cultural rights among the claim type variables in the regression analysis. Nonetheless, it is significant that claims of violations of these rights were rejected in half of these cases, most notably in the IACHR's 2009 decision that El Salvador's failure to provide free anti-retroviral drugs to HIV/AIDS patients does not constitute a violation of Article $26 .{ }^{67}$ In this case, the IACHR interpreted states' economic, social, and cultural rights obligations primarily as a negative "obligation not to adopt regressive measures" dismantling the social safety net. ${ }^{68}$ This is consistent with the arguments of scholars who maintain that the implicit rights referenced in Article 26 are quite limited and that this article cannot reasonably be interpreted as incorporating all internationally recognized economic, social, and cultural rights. ${ }^{69}$ Consequently, there has been little development of Article 26 as a positive obligation and little to encourage further claims. As current IACHR President James Cavallaro notes, "the effectiveness of the InterAmerican system in protecting economic, social, and cultural rights has been practically nil." ${ }^{\prime 0}$ This likely reflects a hesitancy to impose obligations upon states to which they clearly did not consent when ratifying the Convention as well as concern over such obligations being potentially unmanageable for the developing states that comprise the majority of the OAS's membership. ${ }^{71}$ However, like the relative lack of success of equality-based claims, it does at least superficially fit critics' narrative of a system that has neglected social justice issues.

65 American Convention on Human Rights (Nov. 22, 1969). OAS Treaty Series No. 36.

66 Jehovah's Witnesses, Case 2137, Inter-Am. Comm'n H.R., Report No. 31/78, OEA/Ser.L/V/ II.47, doc. 13 rev. 1 (1979); Milton García Fajardo et al., Case 11.381, Inter-Am. Comm’n H.R., Report No. 100/01, OEA/Ser.L/V/II.114, doc. 5 rev. 1 (2002); Oscar Elías Biscet et al., Case 12.476, Inter-Am. Comm'n H.R., Report No. 67/06, OEA/Ser.L/V/II.127, doc. 4 rev. 1 (2007); Grand Chief Michael Mitchell, Case 12.435, Inter-Am. Comm'n H.R., Report No. 61/08, OEA/Ser.L/V/II.134, doc. 5 rev. 1 (2009); Jorge Odir Miranda Cortez et al., Case 12.249, Inter-Am. Comm'n H.R., Report No. 27/09, OEA/Ser.L/V/II, doc. 51 corr. 1 (2009); National Association of Ex-Employees of the Peruvian Social Security Institute et al., supra note 59 .

67 Jorge Odir Miranda Cortez et al., supra note 66.

68 Id. 9106.

69 See RUIZ-CHIRIBOGA, Oswaldo R. The American Convention and the Protocol of San Salvador: Two Intertwined Treaties. Netherlands Quarterly of Human Rights, 2013, vol. 31, no. 2, p. 159.

70 CAVALLARO, James L. and SCHAFFER, Emily J. Less as More: Rethinking Supranational Litigation of Economic and Social Rights in the Americas. Hastings Law Journal, 2004, vol. 56 , no. 2, p. 226.

71 RUIZ-CHIRIBOGA, supra note 69, at 173. 


\section{Conclusions}

This article has shed light upon the dynamics of the IACHR's decision-making processes by conducting the first comprehensive statistical analysis of its merits jurisprudence. The results indicate that the allegations of bias that have been leveled against the Inter-American human rights system are generally offbase. Not only has the system been consistent in its disposition of claims against left-wing and right-wing governments, it has shown neither favoritism toward its major funders nor against the Anglophone Caribbean states that have felt culturally alienated from the system. Also, although the IACHR has been more likely to reject claims based upon rights to equality and economic, social, and cultural rights, this appears to be driven more by concern for maintaining judicially manageable standards of review than by any ideological aversion to such claims per se. The one area in which critiques of the system have been on the mark is its civil and political rights jurisprudence, where the IACHR's activist approach has stood apart from its approach to some of the Convention and Declaration's other rights guarantees (although most would likely consider this a feature rather than a bug). It is important to note, however, that this analysis has been limited to the decision-making stage of litigation before the IACHR. Future research along these lines that shifts the analysis to the agenda-setting stage (i.e. to the IACHR's decisions on admissibility) may find different dynamics at work. Nonetheless, this first cut is significant insofar as it provides further reason to be skeptical of calls for radical change to the system such as those that led to the recent reform process. While it is likely that the system will continue to come under attack from states whose human rights records place them in the system's crosshairs, its record thus far is largely one of successful transcendence of the ideological and other biases that sometimes color judicial behavior.

\section{References (alphabetical order)}

American Convention on Human Rights (Nov. 22, 1969). OAS Treaty Series No. 36.

ARRIAGADA, Milenko B.G. The New Legitimacy Challenges of Adjudication at the InterAmerican Human Rights System in the Context of Latin American Democracies. SJD dissertation, American University, 2015.

BIRON, Carey L. Controversial Inter-American Reforms Process to Continue. [online]. Available at: <http://www.ipsnews.net/2013/03/controversial-inter-americanreforms-process-to-continue/>

BOYLE, Elizabeth H. and THOMPSON, Melissa. National Politics and Resort to the European Commission on Human Rights. Law \& Society Review, 2001, vol. 35, no. 2, pp. 321-44.

BURGORGUE-LARSEN, Laurence and ÚBEDA de TORRES, Amaya. The Inter-American Court of Human Rights: Case Law and Commentary. Oxford: Oxford University Press, 2011.

CAROZZA, Paolo. The Anglo-Latin Divide and the Future of the Inter-American System of Human Rights. Notre Dame Journal of International \& Comparative Law, 2015, vol. 5, no. 1, pp. 153-70. 
CAVALLARO, James L. and SCHAFFER, Emily J. Less as More: Rethinking Supranational Litigation of Economic and Social Rights in the Americas. Hastings Law Journal, 2004 , vol. 56 , no. 2 , pp. $217-82$.

CAVALLARO, James L. and BREWER, Stephanie E. Reevaluating Regional Human Rights Litigation in the $21^{\text {st }}$ Century: The Case of the Inter-American Court. American Journal of International Law, 2008, vol. 102, no. 4, pp. 768-827.

Chipping at the Foundations. [online]. Available at: <http://www.economist.com/ node/21556599>

CONCEPCIÓN, Natasha P. The Legal Implications of Trinidad \& Tobago's Withdrawal from the American Convention on Human Rights. American University International Law Review, 2001, vol. 16, no. 3, pp. 847-90.

Correa Calls for New Inter-American Human Rights System. [online]. Available at:

$<$ https://www.efe.com/efe/english/life/correa-calls-for-new-inter-american-humanrights-system/50000263-3064355>

DULITZKY, Ariel E. Too Little, Too Late: The Pace of Adjudication of the Inter-American Commission on Human Rights. Loyola of Los Angeles International \& Comparative Law Review, 2013, vol. 35, no. 2, pp. 131-208.

EPSTEIN, David et al. Democratic Transitions. American Journal of Political Science, 2006, vol. 50, no. 3, pp. 551-69.

GROSSMAN, Claudio. Freedom of Expression in the Inter-American System for the Protection of Human Rights. Nova Law Review, 2001, vol. 25, no. 2, pp. 411-42.

GROSSMAN, Claudio. The Inter-American System of Human Rights: Challenges for the Future. Indiana Law Journal, 2008, vol. 83, no. 4, pp. 1267-82.

GROSSMAN, Claudio. Challenges to Freedom of Expression Within the Inter-American System: A Jurisprudential Analysis. Human Rights Quarterly, 2012, vol. 34, no. 2, pp. 361-403.

HELFER, Laurence R. Overlegalizing Human Rights: International Relations Theory and the Commonwealth Caribbean Backlash against Human Rights Regimes. Columbia Law Review, 2002, vol. 102, no. 7, pp. 1832-1911.

HOLMUND, Caroline. Why Latin America Is Refusing to Follow the US on Human Rights. [online]. Available at: <https://www.foreignpolicyjournal.com/2014/04/10/why-latin-america-is-refusing-to-follow-the-us-on-human-rights/>

INGLEHART, Ronald and WELZEL, Christian. Modernization, Cultural Change, and Democracy. Cambridge: Cambridge University Press, 2005.

INTER-AMERICAN COMMISSION ON HUMAN RIGHTS. The Death Penalty in the Inter-American Human Rights System: From Restrictions to Abolition. Washington: Organization of American States, 2011.

MORAVCSIK, Andrew. The Origins of Human Rights Regimes: Democratic Delegation in Postwar Europe. International Organization, 2000, vol. 54, no. 2, pp. 217-52.

NEUMAN, Gerald L. Import, Export, and Regional Consent in the Inter-American Court of Human Rights. European Journal of International Law, 2008, vol. 19, no. 1, pp. 101-23. OAS Concludes Formal Inter-American Human Rights "Strengthening" Process, but Dialogue Continues on Contentious Reforms. [online]. Available at: <http:// www.ijrcenter.org/2013/03/24/oas-concludes-formal-inter-american-human-rightsstrengthening-process-but-dialogue-continues-on-contentious-reforms/>

OPPENHEIMER, Andrés. Trump May Weaken OAS - And Efforts to Restore Democracy in Venezuela. [online]. Available at: <http://www.miamiherald.com/news/local/newscolumns-blogs/andres-oppenheimer/article138719758.html> 
PICQ, Manuela. Is the Inter-American Commission on Human Rights Too Progressive? [online]. Available at: <http://www.aljazeera.com/indepth/opinion/2012/06/2012658344220937.html>

PINTO, Mónica. The Crisis of the Inter-American System. Proceedings of the Annual Meeting of the American Society of International Law, 2013, vol. 107, pp. 127-29.

President Correa: We Need to Create a Human Rights System for Latin America. [online]. Available at: <http://www.andes.info.ec/en/news/president-correa-we-need-createhuman-rights-system-latin-america.html>

PRZEWORSKI, Adam et al. Democracy and Development: Political Institutions and WellBeing in the World, 1950-1990. Cambridge: Cambridge University Press, 2000.

RIVERA JUARISTI, Francisco J. US Exceptionalism and the Strengthening Process of the Inter-American Human Rights System. Human Rights Brief, 2013, vol. 20, no. 2, pp. 19-25.

ROGIN, Josh. House Panel Votes to Defund the OAS. [online]. Available at: <http://foreignpolicy.com/2011/07/20/house-panel-votes-to-defund-the-oas/>

RUIZ-CHIRIBOGA, Oswaldo R. Is Ecuador That Wrong? Analyzing the Ecuadorian Proposals Concerning the Special Rapporteurship on Freedom of Expression of the Inter-American Commission on Human Rights. Human Rights Brief, 2013, vol. 20, no. 2, pp. 26-33.

RUIZ-CHIRIBOGA, Oswaldo R. The American Convention and the Protocol of San Salvador: Two Intertwined Treaties. Netherlands Quarterly of Human Rights, 2013, vol. 31 , no. 2, pp. 156-83.

Rules of Procedure of the Inter-American Commission on Human Rights (Mar. 18, 2013). Reprinted in Basic Documents in the Inter-American System, 2011.

SHAVER, Lea. The Inter-American Human Rights System: An Effective Institution for Regional Rights Protection? Washington University Global Studies Law Review, 2010, vol. 9, no. 4, p. 639-76.

SHELTON, Dinah. The Rules and Reality of Petition Procedures in the Inter-American Human Rights System. Notre Dame Journal of International \& Comparative Law, 2015, vol. 5, no. 1 , pp. 1-28.

Statute of the Inter-American Commission on Human Rights (Oct. 31, 1979). Reprinted in Basic Documents in the Inter-American System, 2011.

WHITE, Robin C.A. and BOUSSIAKOU, Iris. Separate Opinions in the European Court of Human Rights. Human Rights Law Review, 2009, vol. 9, no. 1, pp. 47-51.

WILSON, Richard J. The United States' Position on the Death Penalty in the Inter-American Human Rights System. Santa Clara Law Review, 2002, vol. 42, no. 4, pp. 1159-90.

ZSCHIRNT, Simon and MENALDO, Mark. International Insurance? Democratic Consolidation and Support for International Human Rights Regimes. International Journal of Transitional Justice, 2014, vol. 8, no. 3, pp. 452-75.

\section{Inter-American Commission on Human Rights}

Andrea Mortlock, Case 12.534, Inter-Am. Comm'n H.R., Report No. 63/08, OEA/Ser.L/V/ II.134, doc. 5 rev. 1 (2009).

'Baby Boy,' Case 2141, Inter-Am. Comm'n H.R., Report No. 23/81, OEA/Ser.L/V/II.54, doc. 9 rev. 1 (1981).

Benedict Jacob, Case 12.158, Inter-Am. Comm'n H.R., Report No. 56/02, OEA/Ser.L/V/ II.117, doc. 1 rev. 1 (2003).

Chad Roger Goodman, Case 12.265, Inter-Am. Comm'n H.R., Report No. 78/07, OEA/ 
Ser.L/V/II.130, doc. 22 rev. 1 (2007).

Coard et al., Case 10.951, Inter-Am. Comm'n H.R., Report No. 109/99, OEA/Ser.L/V/ II.106, doc. 6 rev. 1 (1999).

Community of the Rio Negro of the Maya Achi Indigenous People and its Members, Case 12.649, Inter-Am. Comm'n H.R., Report No. 86/10, OEA/Ser.L/V/II, doc. 5 rev. 1 (2011).

Dave Sewell, Case 12.347, Inter-Am. Comm'n H.R., Report No. 76/02, OEA/Ser.L/V/ II.117, doc. 1 rev. 1 (2003).

Davlin Morris, Case 3552, Inter-Am. Comm'n H.R., Report No. 60/82, OEA/Ser.L/V/ II.61, doc. 22 rev. 1 (1983).

Denton Aitken, Case 12.275, Inter-Am. Comm'n H.R., Report No. 58/02, OEA/Ser.L/V/ II.117, doc. 1 rev. 1 (2003).

Desmond McKenzie et al., Case 12.023, Inter-Am. Comm'n H.R., Report No. 41/00, OEA/Ser.L/V/II.106, doc. 6 rev. 1 (1999).

Donnason Knights, Case 12.028, Inter-Am. Comm'n H.R., Report No. 47/01, OEA/ Ser.L/V/II.111, doc. 20 rev. 1 (2001).

Earl Pratt, Case 9054, Inter-Am. Comm'n H.R., Report No. 13/84, OEA/Ser.L/V/II.66, doc. 10 rev. 1 (1985).

Eduardo Kimel, Case 12.450, Inter-Am. Comm'n H.R., Report No. 111/06, OEA/Ser.L/V/ II.130, doc. 22 rev. 1 (2007).

Emilio Palacio, Carlos Nicolás Pérez Lapentti, Carlos Pérez Barriga, and César Pérez Barriga, Precautionary Measures 406/11, Inter-Am. Comm'n H.R., OEA/Ser.L/V/II.147, doc. 1 rev. 1 (2013).

Grand Chief Michael Mitchell, Case 12.435, Inter-Am. Comm'n H.R., Report No. 61/08, OEA/Ser.L/V/II.134, doc. 5 rev. 1 (2009).

Haitian Interdiction, Case 10.675, Inter-Am. Comm'n H.R., Report No. 51/96, OEA/ Ser.L/V/II.95, doc. 7 rev. 1 (1997).

Haniff Hilaire et al., Case 11.816, Inter-Am. Comm'n H.R., Report No. 43/98, OEA/ Ser.L/V/II.106, doc. 6 rev. 1 (1999).

Jehovah's Witnesses, Case 2137, Inter-Am. Comm'n H.R., Report No. 31/78, OEA/ Ser.L/V/II.47, doc. 13 rev. 1 (1979).

Jessica Lenahan (Gonzales) et al., Case 12.626, Inter-Am. Comm'n H.R., Report No. 80/11, OEA/Ser.L/V/II, doc. 69 rev. 1 (2011).

Jorge Odir Miranda Cortez et al., Case 12.249, Inter-Am. Comm'n H.R., Report No. 27/09, OEA/Ser.L/V/II, doc. 51 corr. 1 (2009).

Joseph Thomas, Case 12.183, Inter-Am. Comm'n H.R., Report No. 127/01, OEA/Ser.L/V/ II.114, doc. 5 rev. 1 (2002).

Juan Pablo Olmedo Bustos et al., Case 11.803, Inter-Am. Comm'n H.R., Report No. 31/98, OEA/Ser.L/V/II.102, doc. 6 rev. 1 (1999).

Karen Atala and Daughters, Case 12.502, Inter-Am. Comm'n H.R., Report No. 139/09, OEA/Ser.L/V/II, doc. 51 corr. 1 (2009).

Kuna Indigenous People of Madungandi and Embera Indigenous People of Bayano and their Members, Case 12.354, Inter-Am. Comm'n H.R., Report No. 125/12, OEA/ Ser.L/V/II.147, doc. 1 rev. 1 (2013).

Lennox Boyce et al., Case 12.480, Inter-Am. Comm'n H.R., Report No. 03/06, OEA/ Ser.L/V/II.127, doc. 4 rev. 1 (2007).

Leroy Lamey et al., Case 11.826, Inter-Am. Comm'n H.R., Report No. 49/01, OEA/ Ser.L/V/II.111, doc. 20 rev. 1 (2001). 
Lyndon Champagnie, Case 7505, Inter-Am. Comm'n H.R., Report No. 27/86, OEA/ Ser.L/V/II.68, doc. 8 rev. 1 (1986).

Marcelino Hanríquez et al., Case 11.784, Inter-Am. Comm'n H.R., Report No. 73/00, OEA/Ser.L/V/II.111, doc. 20 rev. 1 (2001).

Maria Eugenia Morales de Sierra, Case 11.625, Inter-Am. Comm'n H.R., Report No. 4/01, OEA/Ser.L/V/II.111, doc. 20 rev. 1 (2001).

Mary and Carrie Dann, Case 11.140, Inter-Am. Comm'n H.R., Report No. 75/02, OEA/ Ser.L/V/II.117, doc. 1 rev. 1 (2003).

Mauricio Herrera Ulloa, Case 12.367, Inter-Am. Comm'n H.R., Report No. 64/02, OEA/ Ser.L/V/II.118, doc. 5 rev. 2 (2003).

Maya Indigenous Communities of the Toledo District, Case 12.053, Inter-Am. Comm'n H.R.,

Report No. 40/04, OEA/Ser.L/V/II.122, doc. 5 rev. 1 (2005).

Michael Edwards et al., Case 12.067, Inter-Am. Comm'n H.R., Report No. 48/01, OEA/ Ser.L/V/II.111, doc. 20 rev. 1 (2001).

Milton García Fajardo et al., Case 11.381, Inter-Am. Comm'n H.R., Report No. 100/01, OEA/Ser.L/V/II.114, doc. 5 rev. 1 (2002).

National Association of Ex-Employees of the Peruvian Social Security Institute et al., Case 12.670, Inter-Am. Comm'n H.R., Report No. 38/09, OEA/Ser.L/V/II, doc. 51 corr. 1 (2009).

Noel Riley, Case 3102, Inter-Am. Comm'n H.R., Report No. 25/81, OEA/Ser.L/V/II.54, doc. 9 rev. 1 (1981).

Oscar Elías Biscet et al., Case 12.476, Inter-Am. Comm'n H.R., Report No. 67/06, OEA/ Ser.L/V/II.127, doc. 4 rev. 1 (2007).

Paul Lallion, Case 11.765, Inter-Am. Comm'n H.R., Report No. 55/02, OEA/Ser.L/V/ II.117, doc. 1 rev. 1 (2003).

Pedro Peredo Valderrama, Case 11.103, Inter-Am. Comm'n H.R., Report No. 42/00, OEA/Ser.L/V/II.106, doc. 6 rev. 1 (1999).

Peter Cash, Case 12.231, Inter-Am. Comm'n H.R., Report No. 12/14, OEA/Ser.L/V/ II.150, doc. 16 rev. 1 (2014).

Rafael Ferrer-Mazorra et al., Case 9903, Inter-Am. Comm'n H.R., Report No. 51/01, OEA/Ser.L/V/II.111, doc. 20 rev. 1 (2001).

Residents of the Village of Chichupac and Neighboring Communities, Case 12.788, InterAm. Comm'n H.R., Report No. 100/14, OEA/Ser.L/V/II.150, doc. 16 rev. 1 (2015).

Ricardo Israel Zipper, Case 12.470, Inter-Am. Comm'n H.R., Report No. 110/09, OEA/ Ser.L/V/II, doc. 51 corr. 1 (2009).

Roosevelt Edwards, Case 7604, Inter-Am. Comm'n H.R., Report No. 7/84, OEA/Ser.L/V/ II.63, doc. 10 rev. 1 (1984).

Rudolph Baptiste, Case 11.743, Inter-Am. Comm'n H.R., Report No. 38/00, OEA/Ser.L/V/ II.111, doc. 20 rev. 1 (2001).

Statehood Solidarity Committee, Case 11.204, Inter-Am. Comm'n H.R., Report No. 98/03, OEA/Ser.L/V/II.118, doc. 5 rev. 2 (2003).

Tyrone Dacosta Cadogan, Case 12.645, Inter-Am. Comm'n H.R., Report No. 60/08, OEA/ Ser.L/V/II.134, doc. 5 rev. 1 (2009).

Undocumented Workers, Case 12.834, Inter-Am. Comm'n H.R., Report No. 50/16, OEA/ Ser.L/V/II.159 (2016).

Wayne Smith, Hugo Armendariz et al., Case 12.562, Inter-Am. Comm'n H.R., Report No. 81/10, OEA/Ser.L/V/II, doc. 5 rev. 1 (2011). 
ICLR, 2017, Vol. 17, No. 1.

Wesley Cuthbert, Case 9190, Inter-Am. Comm’n H.R., Report No. 28/86, OEA/Ser.L/V/ II.68, doc. 8 rev. 1 (1986).

Yean and Bosico Children, Case 12.189, Inter-Am. Comm'n H.R., Report No. 30/03, OEA/Ser.L/V/II.118, doc. 5 rev. 2 (2003).

\section{Inter-American Court of Human Rights}

Granier et al. (Radio Caracas Televisión) v. Venezuela, Preliminary Objections, Merits, Reparations, and Costs, Judgment, Inter-Am. Ct. H.R. (ser. C) No. 293 (June 22, 2015).

Juridical Condition and Rights of the Undocumented Migrants, Advisory Opinion, InterAm. Ct. H.R. (ser. A) No. 18 (Sept. 17, 2003).

López Mendoza v. Venezuela, Merits, Reparations, and Costs, Judgment, Inter-Am. Ct. H.R. (ser. C) No. 233 (Sept. 11, 2011). 